\title{
Perancangan Dan Implementasi Sistem Pengaturan Kecepatan Motor Bldc Menggunakan Kontroler Pi Berbasiskan Neural-Fuzzy Hibrida Adaptif
}

\author{
Agung Setyadi Wicaksono, Rushdianto Effendie A. K., dan Eka Iskandar \\ Jurusan Teknik Elektro, Fakultas Teknologi Industri, Institut Teknologi Sepuluh Nopember (ITS) \\ Jl. Arief Rahman Hakim, Surabaya 60111 \\ E-mail: agungsetyadiw@gmail.com, rusdhi@elect-eng.its.ac.id, iskandar@elect-eng.its.ac.id
}

\begin{abstract}
Abstrak-Perkembangan di bidang otomotif mengantarkan kita pada kendaraan tanpa menggunakan bahan bakar minyak. Mobil listrik menjadi inovasi terbaru dengan tujuan utama untuk melepaskan ketergantungan pada bahan bakar minyak. Penelitian yang telah ada memaparkan bahwa motor listrik yang sesuai untuk menggerakkan mobil listrik adalah motor Brushless Direct Current (BLDC). Beberapa keunggulan motor BLDC antara lain adalah suara halus, ukuran kompak, torsi besar, efisiensi tinggi, memiliki umur pakai yang panjang, dan mudah dikontrol. Performa dan kecepatan motor BLDC dapat terganggu apabila bekerja pada kondisi berbeban. Oleh karena itu, dibutuhkan pengaturan kecepatan menggunakan sebuah kontroler yang dapat menjaga kecepatan motor BLDC sesuai set-point meskipun sedang beroperasi pada kondisi berbeban.Kontroler yang digunakan untuk mengatur kecepatan motor BLDC adalah kontroler Proposional Integral (PI) berbasiskan Neural-Fuzzy Hibrida Adaptif. Kontroler PI dipilih karena dapat mengeliminasi steady-state error. Sedangkan Neural-Fuzzy Hibrida Adaptif merupakan kombinasi antara Fuzzy dan Neural-Network. Fuzzy digunakan untuk penentuan parameter kontroler PI. Parameter kontroler PI didapatkan dari Neural-Network. Karakteristik respon terhadap hasil implementasi memiliki settling time 20 detik, overshoot sebesar 1,1\%, dan time constant 7,7 detik.
\end{abstract}

Kata Kunci-Brushless DC, Hybrid Adaptive Neural-Fuzzy, Propotional and Integral (PI) Controller.

\section{PENDAHULUAN}

Perkembangan di bidang otomotif mengantarkan kita pada kendaraan tanpa menggunakan bahan bakar minyak. Mobil listrik menjadi inovasi terbaru dengan tujuan utama untuk melepaskan ketergantungan pada bahan bakar minyak [1].

Penelitian yang telah ada memaparkan bahwa motor listrik yang sesuai untuk menggerakkan mobil listrik adalah motor Brushless Direct Current (BLDC). Motor BLDC dipilih karena memiliki beberapa keunggulan apabila dibandingkan dengan motor listrik yang lain. Beberapa keunggulan yang menjadi pertimbangan pada pemilihan motor BLDC antara lain adalah suara halus, ukuran kompak, torsi besar, efisiensi tinggi, memiliki umur pakai yang panjang, dan mudah dikontrol. Motor BLDC beroperasi tanpa menggunakan sikat sehingga rugi gesekan pada sikat dapat dihilangkan [1].

Performa dan kecepatan motor BLDC dapat terganggu apabila bekerja pada kondisi berbeban. Oleh karena itu, dibutuhkan pengaturan kecepatan menggunakan sebuah kontroler yang dapat menjaga kecepatan motor BLDC sesuai set-point meskipun sedang beroperasi pada kondisi berbeban [2].

Kontroler yang digunakan untuk mengatur kecepatan motor BLDC adalah kontroler Proposional Integral (PI) berbasiskan Neural-Fuzzy Hibrida Adaptif. Kontroler PI dipilih karena dapat mengeliminasi steady-state error. Sedangkan Neural-Fuzzy Hibrida Adaptif merupakan kombinasi antara Fuzzy Logic dan Neural Network. Sedangkan Neural-Fuzzy Hibrida Adaptif merupakan kombinasi antara Fuzzy dan Neural Network. Fuzzy digunakan untuk penentuan parameter kontroler PI. Parameter kontroler PI didapatkan dari Neural-Network.

\section{TEORI PENUNJANG}

\section{A. BLDC [2]}

Motor BLDC merupakan pilihan tepat untuk aplikasi yang membutuhkan keandalan tinggi, efisiensi tinggi, dan rasio power-to-volume tinggi. Secara umum, motor BLDC dianggap sebagai motor dengan performa tinggi yang mampu menghasilkan torsi yang besar pada range kecepatan yang besar. Motor BLDC adalah turunan dari motor DC yang paling umum digunakan, yaitu motor DC dengan sikat dan mereka memiliki kurva karakteristik torsi dan kecepatan yang sama. Perbedaan utama motor BLDC dan DC adalah penggunaan sikat. Motor BLDC tidak memiliki sikat dan harus terkomutasi secara elektronik.

Komutasi merupakan perubahan fase arus motor pada waktu yang tepat untuk menghasilkan torsi rotasional. Dalam motor DC dengan sikat, motor memiliki komutator fisik yang digerakkan dengan sikat untuk memindahkan rotor. Dalam motor BLDC, kekuatan arus listrik magnet permanen menyebabkan motor untuk bergerak, sehingga komutator fisik tidak diperlukan.

Motor BLDC sangat handal karena tidak memiliki sikat yang dapat aus dan harus diganti. Ketika dioperasikan dalam kondisi optimal, usia motor dapat lebih dari 10000 jam. Untuk aplikasi jangka panjang, hal ini dapat menjadi keuntungan yang besar. Setiap kali motor rusak atau perlu diganti, plant atau bagian dari plant harus dimatikan. Hal ini membutuhkan waktu dan uang, tergantung pada berapa lama waktu yang dibutuhkan untuk mengganti komponen yang aus dan rusak agar plant dapat berjalan seperti semula. Meskipun motor BLDC memakan biaya lebih dari motor DC dengan 
sikat, hal ini akan sepadan seiring dengan banyaknya waktu dan uang yang dihabiskan motor DC dengan sikat.

Motor yang digunakan adalah motor Air Conditioner (AC) Daikin Inverter. Motor Daikin Inverter ditunjukkan pada Gambar 1.

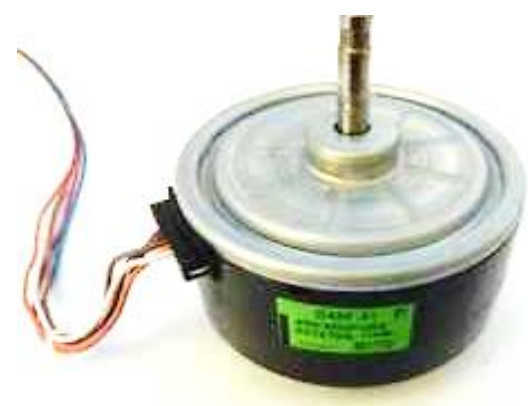

Gambar 1 Motor Daikin Inverter

\section{B. Fuzzy Logic [3]}

Dasar dari fuzzy logic adalah himpunan fuzzy. Zadeh memperkenalkan konsep himpunan fuzzy sebagai perluasan dari himpunan konvensional. Suatu himpunan fuzzy adalah koleksi dari bilangan real yang memiliki keanggotaan parsial dalam himpunan.

Logika fuzzy sudah digunakan dalam dalam bidang kontrol. Secara umum, sistem fuzzy terdiri dari beberapa komponen, yaitu fuzzification, fuzzy rule base, fuzzy inference engine, dan defuzzifier seperti yang ditunjukkan pada Gambar 2 .

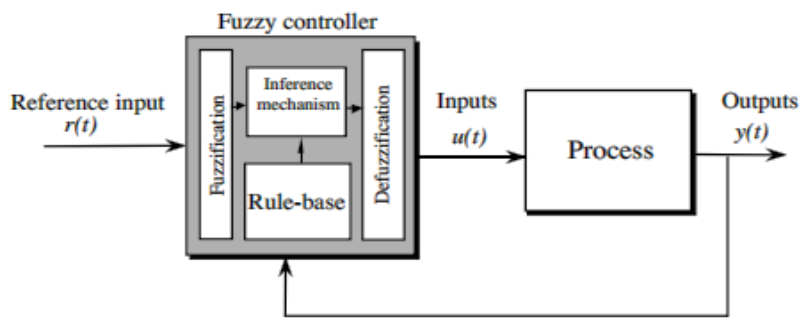

Gambar 2 Fuzzy Controller

Fuzzy rule base berisi pernyataan-pernyataan logika fuzzy, yang berbentuk pernyataan IF-THEN. Bentuk umum pernyataan fuzzy ditunjukkan pada Persamaan 1.

$$
\text { IF } x_{1} \text { is } A_{1}^{1} \text { and ... and } x_{n} \text { is } A_{n}^{1} \text { THEN } y \text { is } B^{1}
$$

$\mathrm{A}_{1}{ }^{1}$ dan $\mathrm{B}^{1}$ adalah himpunan fuzzy, sedangkan $\mathrm{x}=\left(\mathrm{x}_{1}, \mathrm{x}_{2}\right.$, $\left.\ldots, \mathrm{x}_{\mathrm{n}}\right)^{\mathrm{T}}$ dan $\mathrm{y}$ adalah input dan output dari variabel fuzzy.Fuzzy inference engine merupakan suatu modul pembuat keputusan dalam kontroler fuzzy yang berfungsi untuk menentukan suatu kesimpulan berdasarkan pada seberapa besar pengaruh setiap rule dalam rule base berdasarkan pada nilai input yang masuk.

Fuzzifier digunakan untuk memetakan nilai variabel di dunia nyata kedalam himpunan fuzzy. Pemetaan nilai variabel dilakukan dengan menggunakan fungsi keanggotaan. Formulasi singleton, gaussian, dan triangular fuzzyfier ditunjukkan pada Persamaan 2, 3, dan 4.

$$
\mu A^{\prime}(x)=\left\{\begin{array}{l}
1 \text { if } x=x * \\
0 \text { otherwise }
\end{array}\right.
$$

$$
\begin{aligned}
\mu A^{\prime}(x)=e^{-\left(\frac{x_{1}-x_{1}^{*}}{a_{1}}\right)} & * \ldots . \\
& * e^{-\left(\frac{x_{n}-x_{n}^{*}}{a_{n}}\right)}
\end{aligned}
$$

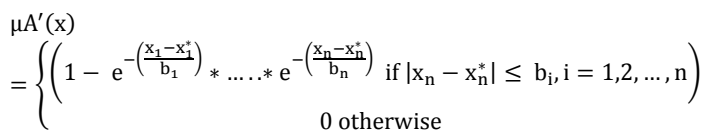

Defuzzifier mengembalikan hasil perhitungan fuzzy menjadi variabel yang sesuai di dunia nyata. Sama dengan fuzzifier, defuzzifier juga menggunakan fungsi keanggotaan untuk memetakan nilai himpunan fuzzy menjadi variabel nyata. Beberapa metode defuzzifier adalah:

1) Center of gravity defuzzifier. Center of gravity dinyatakan dengan $\mathrm{y}^{*}$, menunjukan pusat area yang diliputi oleh fungsi keanggotaan.

2) Center average defuzzifier. Center average menunjukan weight average dari titik tengah (center) masing-masing fungsi keanggotaan.

3) Maximum defuzzifier. Maximum defuzzifier memilih nilai tertinggi sebagai $\mathrm{y}^{*}$. Terdapat 3 pilihan, yaitu smallest of maxima, largest of maxima atau mean of maxima.

\section{Jaringan Syaraf Tiruan (JST) [4]}

JST adalah suatu program komputer yang dibuat berdasarkan cara kerja otak manusia. JST melakukan proses pelatihan yang meniru kerja otak manusia. Proses komputasi pada JST diilhami dari struktur dan cara kerja otak manusia. Pada jaringan syaraf otak manusia, informasi disalurkan dari satu neuron ke neuron lainnya. Sementara pada JST proses penyaluran informasi dari satu neuron ke neuron lainnya diimplementasikan pada program komputer. Proses pelatihan JST umumnya menggunakan metode pelatihan backpropagation yang sudah banyak diterapkan pada semua proses pelatihan yang sederhana sampai yang rumit.

Metode pelatihan backpropagation termasuk ke dalam metode pelatihan terawasi (supervisory learning). Supervisory learning adalah metode pelatihan yang memasukan target ke output dalam data untuk proses pelatihan. Metode pelatihan backpropagation telah banyak diaplikasikan dalam berbagai bidang, antara lain: bidang finansial, pengenalan pola tulis tangan, sistem kontrol, dan lain sebagainya. Metode backpropagation banyak diaplikasikan dalam berbagai proses karena metode backpropagation didasarkan pada interkoneksi yang sederhana. Apabila output JST tidak sesuai dengan output yang diinginkan, maka metode backpropagation akan memperbaiki bobot (weight) yang ada pada lapisan tersembunyi (hidden layer) untuk mencapai output JST yang sesuai dengan target output.

Pada dasarnya JST akan diberikan pola input sebagai pola pelatihan maka pola akan menuju ke unit-unit lapisan tersembunyi dan akan diteruskan ke lapisan output. Struktur JST ditunjukkan pada Gambar 3. 


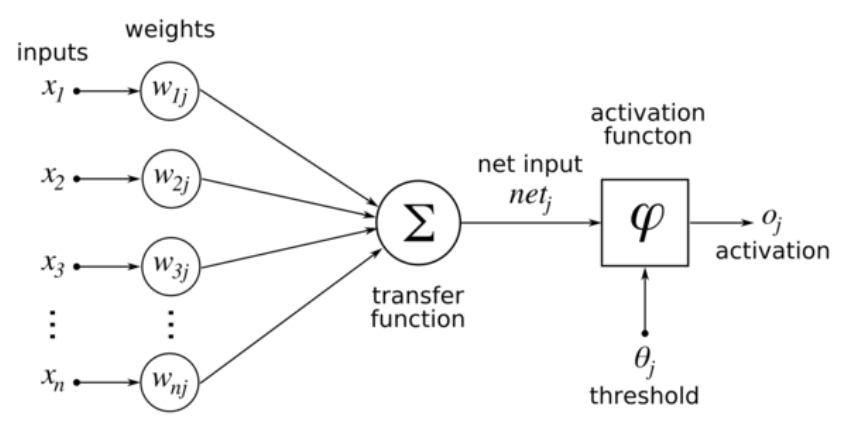

Gambar 3 Struktur JST

\section{Kontroler PI [2]}

Kontroler PI berguna menentukan presisi suatu sistem instrumentasi dengan karakteristik adanya umpan balik pada sistem tesebut. Kontroler PI adalah kontroler konvensional yang banyak dipakai dalam dunia industri. Blok diagram dan persamaan kontroler PI ditunjukkan pada Gambar 4 dan Persamaan 5.

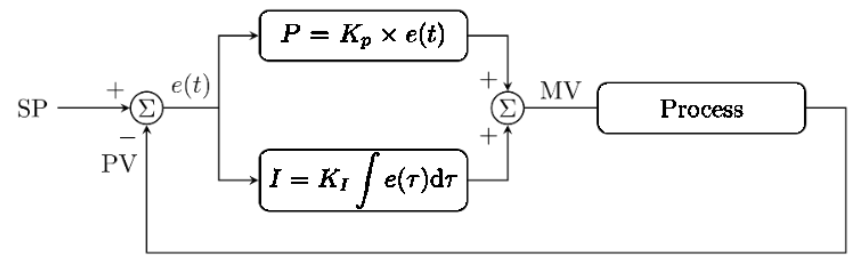

Gambar 4 Blok Diagram Kontroler PI

$$
m v(t)=\left(K_{P} e(t)+\frac{1}{T_{i}} \int_{0}^{t} e(t) d t\right)
$$

Komponen kontroler PI terdiri dari dua jenis yaitu proporsional dan integratif. Komponen proposional dan integral dapat dipakai bersamaan maupun sendiri-sendiri tergantung dari respon yang kita inginkan terhadap suatu plant.

Apabila pada kontroler proporsional nilai $\mathrm{G}(\mathrm{s})=\mathrm{Kp}$ maka $\mathrm{Kp}$ berlaku sebagai gain (penguat) saja tanpa memberikan efek dinamik kepada kinerja kontroler. Penggunaan kontroler proporsional memiliki berbagai keterbatasan karena sifat kontrol yang tidak dinamik. Walaupun demikian dalam aplikasi-aplikasi dasar yang sederhana kontroler proposional mampu memperbaiki respon transien khususnya rise time dan settling time. Kontroler proporsional memiliki keluaran yang sebanding dengan besarnya sinyal kesalahan (selisih antara besaran yang diinginkan dengan output).

Ciri-ciri kontroler proporsional:

1) Apabila nilai $\mathrm{Kp}$ kecil, kontroler proporsional hanya mampu melakukan koreksi kesalahan yang kecil, sehingga akan menghasilkan respon sistem yang lambat (menambah rise time)

2) Apabila nilai Kp dinaikkan, respon sistem akan semakin cepat mencapai keadaan steady state (mengurangi rise time)

3) Namun, apabila nilai Kp diperbesar sehingga mencapai harga yang berlebihan, akan mengakibatkan sistem bekerja tidak stabil atau respon sistem akan berosilasi

4) Apabila nilai $\mathrm{Kp}$ dapat di-set sedemikian sehingga mengurangi error steady state, tetapi tidak menghilangkannya.
Kontroler integral berfungsi untuk menghasilkan respon sistem yang memiliki error steady state nol. Apabila sebuah kontroler tidak memiliki unsur integrator, kontroler proporsional tidak mampu menjamin memiliki keluaran sistem dengan error steady state nol.

Ketika nilai error steady state mendekati nol maka efek kontrol integral semakin kecil. Kontroler integral dapat menghilangkan error steady-state, namun pemilihan Ki yang tidak tepat dapat menyebabkan ketidakstabilan sistem. Pemilihan Ki yang sangat tinggi dapat menyebabkan output berosilasi karena menambah orde sistem.

Keluaran kontroler integral merupakan hasil penjumlahan yang terus menerus dari perubahan input. Ketika sinyal kesalahan tidak mengalami perubahan, maka kontroler integral menjaga keadaan output seperti sebelum terjadinya perubahan input. Sinyal keluaran kontroler integral merupakan luas bidang yang dibentuk oleh kurva error.

Ciri-ciri kontroler proporsional:

1) Apabila nilai $\mathrm{Kp}$ kecil, kontroler proporsional hanya mampu melakukan koreksi kesalahan yang kecil, sehingga akan menghasilkan respon sistem yang lambat (menambah rise time)

2) Apabila nilai Kp dinaikkan, respon sistem akan semakin cepat mencapai keadaan steady state (mengurangi rise time)

3) Namun, apabila nilai Kp diperbesar sehingga mencapai harga yang berlebihan, akan mengakibatkan sistem bekerja tidak stabil atau respon sistem akan berosilasi

4) Apabila nilai $\mathrm{Kp}$ dapat di-set sedemikian sehingga mengurangi error steady state, tetapi tidak menghilangkannya.

\section{PEMODELAN DAN PERANCANGAN}

\section{A. $B L D C$}

Penulis merancang sistem pengaturan kecepatan motor BLDC menggunakan kontroler PI berbasiskan Neural-Fuzzy Hibrida Adaptif. Hibrida merupakan kombinasi antara fuzzy dan neural-network sedangkan adaptif merupakan sifat sistem kendali dimana parameter-parameter sistem kendali dapat menyesuaikan terhadap perubahan kondisi beban. Kontroler fuzzy pada sistem pengaturan kecepatan motor BLDC berfungsi sebagai pengatur nilai $\mathrm{Kp}$ dan $\mathrm{Ki}$ pada kontroler $\mathrm{PI}$, sehingga nilai $\mathrm{Kp}$ dan $\mathrm{Ki}$ menjadi fungsi keanggotaan pada output kontroler fuzzy. Input kontroler fuzzy berupa nilai tegangan beban. Nilai $\mathrm{Kp}$ dan $\mathrm{Ki}$ didapatkan dari proses learning neural-network.

Plant menggunakan sistem kendali negative feedback yang terdiri dari komponen utama yaitu motor BLDC, driver, dan rem elektromagnetik. Driver berfungsi sebagai aktuator yang menghubungkan antara kontroler dengan plant sedangkan rem elektromagnetik berfungsi untuk memberikan efek pembebanan pada motor BLDC. Sinyal kontrol dari kontroler berupa sinyal PWM yang digunakan sebagai input driver untuk mengatur kecepatan motor BLDC. Pemorograman kontroler dilakukan di MATLAB R2013a sedangkan Arduino bertindak sebagai interface antara komputer dengan driver motor BLDC. Sensor yang digunakan dalam sistem pengaturan kecepatan motor BLDC adalah sensor kecepatan 
yang digunakan sebagai negative feedback untuk mengukur kecepatan motor secara aktual. Blok diagram pengaturan kecepatan motor BLDC ditunjukkan pada Gambar 5.

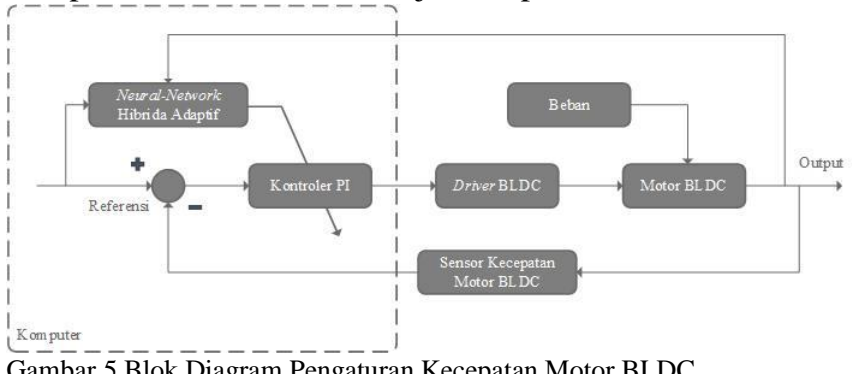

Gambar 5 Blok Diagram Pengaturan Kecepatan Motor BLDC

Perancangan perangkat keras ada dua jenis, yaitu perancangan mekanik dan elektronik. Perancangan mekanik merupakan perancangan komponen utama pada plant, yaitu berupa motor BLDC dan rem elektromagnetik sedangkan perancangan elektronik merupakan perancangan pada kontroler, driver rem, dan rangkaian sensor kecepatan pada plant.

Arduino menerima data dari sensor kecepatan dan mengirimkan data pada komputer kemudian mengirimkan sinyal kontrol ke motor BLDC melaui Arduino Konfigurasi perangkat keras sistem pengaturan kecepatan BLDC ditunjukkan pada Gambar 6

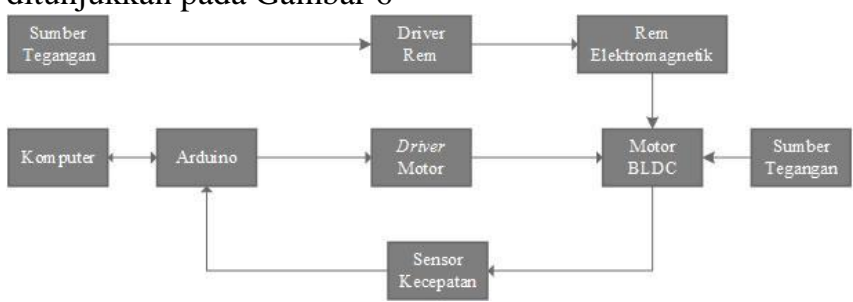

Gambar 6 Konfigurasi Perangkat Keras Sistem Pengaturan Kecepatan BLDC

\section{B. Identifikasi Sistem}

Identifikasi pemodelan sistem pengaturan kecepatan motor BLDC digunakan identifikasi dinamis. Model matematika plant didapatkan melalui toolbox matlab system identification dengan cara meng-input-kan data input-output, melakukan preprocessing, dan memilih bentuk model yang diinginkan. Dalam proses identifikasi, data input-output yang ada dimasukkan ke dalam aplikasi dengan memilih "time domain data" saat menekan akan timbul tulisan "import data". Setelah itu dilakukan preprocessing.

Data yang telah melalui tahap preprocess kemudian dipilih sebagai working data sekaligus validation data dengan cara drag-and-drop kotak yang berisi data tersebut ke kotak working data dan validation data. Kemudian dilakukan identifikasi model dengan memilih "transfer function" setelah meng-klik popout bertuliskan "estimate". Tampilan dari system identification toolbox pada MATLAB ditunjukkan pada Gambar 7.

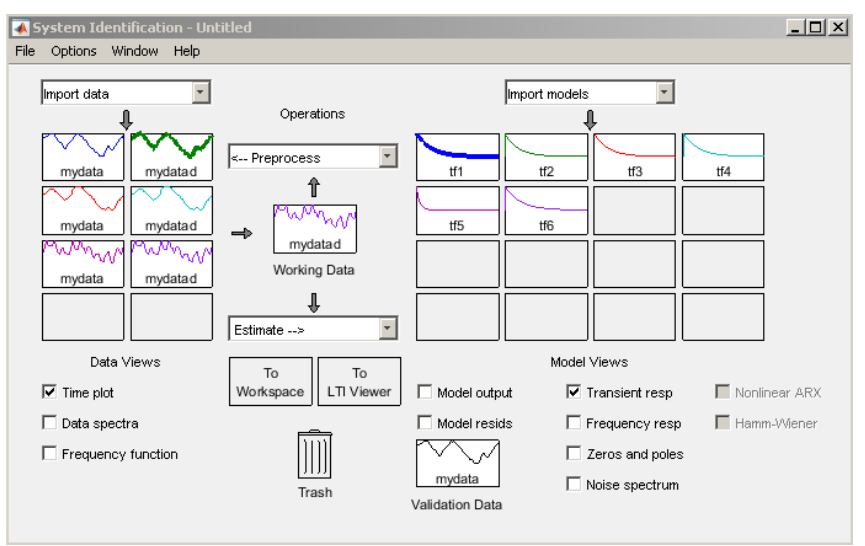

Gambar 7 Tampilan System Identification Toobox MATLAB

Fungsi alih yang didapatkan setelah dilakukan identifikasi menggunakan system identification toolbox ditunjukkan pada Tabel 1.

Tabel 1.

Fungsi Alih Plant Motor BLDC.

\begin{tabular}{cccc}
\hline \hline Beban & $\begin{array}{c}\text { Tegangan } \\
\text { input } \\
\text { beban }\end{array}$ & Fungsi Alih & MSE \\
\hline Minimal & 16 Volt & $\frac{428,8 s+1279}{s^{2}+2,351 s+0,7318}$ & 376,6 \\
Nominal & 20 Volt & $\frac{536,2 s+1969}{s^{2}+3,461 s+1,185}$ & 346,9 \\
Maksimal & 24 Volt & $\frac{460,3 s+1396}{s^{2}+2,47 s+0,8689}$ & 271 \\
\hline \hline
\end{tabular}

C. Perancangan Neural-Fuzzy Hibrida Adaptif

Setelah fungsi alih dari plant didapatkan kemudian melakukan perancangan kontroler untuk masing-masing pembebanan. Kontroler digunakan untuk mengembalikan respon ke nilai set point meskipun motor BLDC diberi beban. Tahapan desain kontroler meliputi perancangan kontroler PI yang didapatkan dari learning Neural-Network dan perancangan kontroler fuzzy PI.

Neural-Network digunakan sebagai tuning parameter PI untuk mengatur kecepatan motor BLDC.

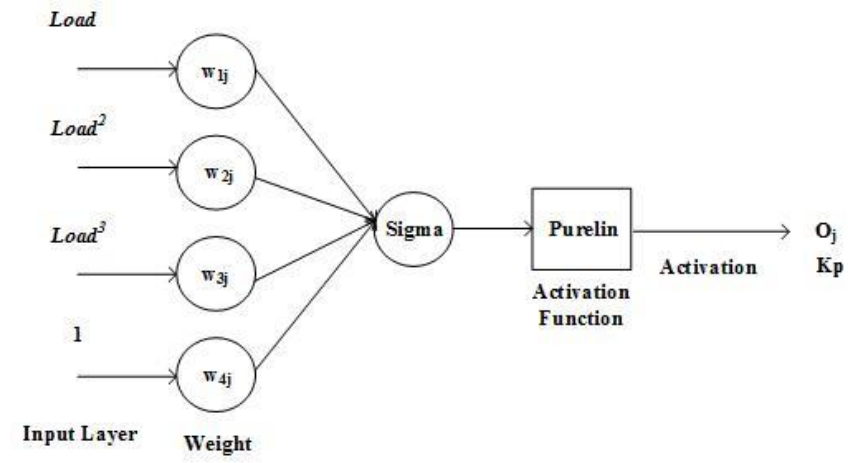

Gambar 8 Struktur Neural-Network untuk Kp 


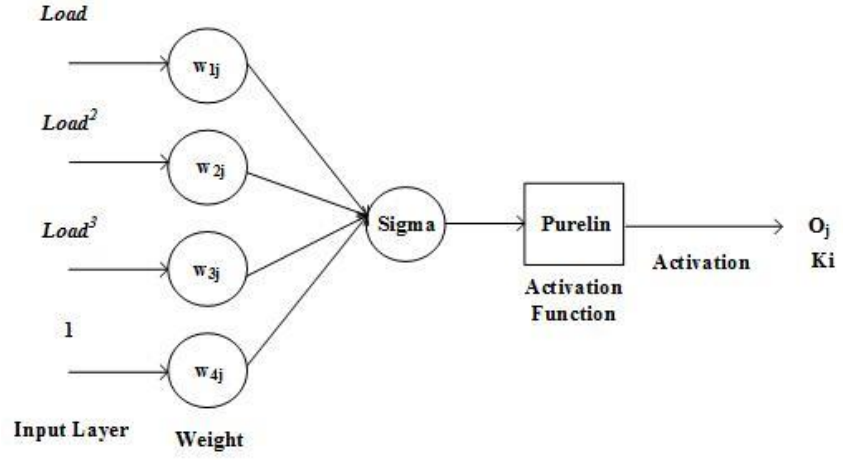

Gambar 9 Struktur Neural-Network untuk Ki

Algoritma pembelajaran neural-network yang dipakai adalah feed forward. Input layer neural-network berupa nilai tegangan beban. Persamaan input layer neural-network ditunjukkan pada Persamaan 6.

$$
O_{j}^{1}=x(j)(j=1,2, \ldots, M)
$$

M meruapakan jumlah variabel input pada input layer, pada neural network digunakan 4 variabel input. Variabel input dari input layer kemudian menuju output layer.

$$
\begin{aligned}
& n e t^{1}=\sum_{j=0}^{M} w_{j}^{1} O_{j}^{1} \\
& O^{2}=\operatorname{purelin}\left(n e t^{1}\right)
\end{aligned}
$$

Untuk merivisi bobot neural-network dipakai algoritma gradient steepest descent sehingga dipenuhi kriteria error kuadarat tiap saat minimum. Formulasi kriteria error kuadrat tiap saat minimum ditunjukkan pada Persamaan 9.

$$
J=\frac{1}{2} e^{2}
$$

Error berupa error Kp dan error Ki. Untuk mendapatkan error $\mathrm{Kp}$ dan error $\mathrm{Ki}$, nilai error sinyal kontrol harus diketahui terlebih dahulu. Error sinyal kontrol ditunjukkan Persamaan 10.

$$
e(u)=(e m(k)-e(k)) * \frac{B}{K}
$$

Error model, em $(k)$, merupakan nilai error yang harus dituju oleh nilai error sesungguhnya. $e(u)$ merupakan error sinyal kontrol plant pengaturan kecepatan motor BLDC. Kemudian, didapatakan nilai error $\mathrm{Kp}$ dan $\mathrm{Ki}$ yang ditunjukkan pada Persamaan 11 dan 12.

$$
\begin{aligned}
& e k p=\frac{e . K p}{u} e(u) \\
& e k i=\frac{e . K i}{u} e(u)
\end{aligned}
$$

Kriteria error kuadrat akan minimum apabila memenuhi formulasi yang ditunjukkan pada Persamaan 13.

$$
\frac{\partial J}{\partial w_{j}}=0
$$

Karena kriteria error kuadarat tiap minimum, $J$, merupakan fungsi kuadrat dari $w_{j}$ maka dapat digambarkan pada Gambar 10.

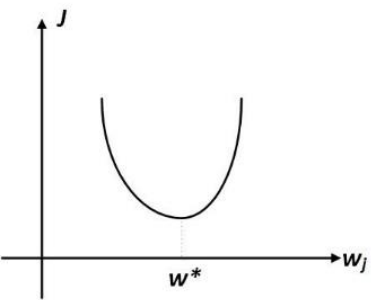

Gambar 10 Fungsi J terhadap $w_{j}$

Kemudian didapatkan persamaan $\frac{\partial J}{\partial w_{j}}$ yang ditunjukkan pada Persamaan 14.

$$
\begin{aligned}
\frac{\partial J}{\partial w_{j}} & =\frac{\partial J}{\partial e} \frac{\partial e}{\partial O_{j}^{2}} \frac{\partial O_{j}^{2}}{\partial n e t^{1}} \frac{\partial n e t^{1}}{\partial w_{j}} \\
\frac{\partial J}{\partial w_{j}} & =-e f^{\prime}\left(O_{j}^{2}\right) x(j)
\end{aligned}
$$

Kemudian didapatkan persamaan gradient steepest descent yang ditunjukkan pada Persamaan 15 .

$$
w_{j}(k+1)=w_{j}(k)+\Delta w * e * f^{\prime}\left(O_{j}^{2}\right) x(j)
$$

Tahap perancangan kontroler fuzzy PI memiliki berberapa tahap yaitu penentuan fungsi keanggotaan dan bentuk fungsi keanggotaan kemudian membuat rule base dan menentukan fungsi keanggotaan pada output.

Kontroler fuzzy pada sistem pengaturan kecepatan motor BLDC berfungsi sebagai pengatur nilai $\mathrm{Kp}$ dan $\mathrm{Ki}$ pada kontroler $\mathrm{PI}$, sehingga nilai $\mathrm{Kp}$ dan $\mathrm{Ki}$ menjadi fungsi keanggotaan pada output kontroler fuzzy. Pada input fuzzy memiliki 1 input yaitu besar beban pengereman yang diberikan.

Kontroler fuzzy PI digunakan untuk mengeluarkan nilai Kp dan Ki sesuai dengan kondisi pembebanan maka dalam rule base memiliki 3 pernyataan di setiap nilai $\mathrm{Kp}$ dan $\mathrm{Ki}$. Misalkan dipilih representasi fungsi keanggotaan input sebagai berikut:

$$
\begin{aligned}
& \text { Beban Minimal }=\mathrm{BK} \\
& \text { Beban Nominal }=\mathrm{BS} \\
& \text { Beban Maksimal }=\mathrm{BB}
\end{aligned}
$$

Maka rule base untuk kontroler fuzzy akan terlihat seperti berikut.

$$
\begin{array}{ll}
\text { If } \mathrm{X}=\mathrm{BK} & \text { Then } \mathrm{K}_{\mathrm{P}}=2,497369583 \\
\text { If } \mathrm{X}=\mathrm{BS} & \text { Then } \mathrm{K}_{\mathrm{P}}=7,911902938 \\
\text { If } \mathrm{X}=\mathrm{BB} & \text { Then } \mathrm{K}_{\mathrm{p}}=14,50763256
\end{array}
$$

Pernyataan diatas merupakan rule base untuk pencarian nilai $\mathrm{K}_{\mathrm{p}}$. Apabila semakin besar pembebanan maka semakin besar nilai $\mathrm{K}_{\mathrm{p}}$ yang digunakan. Kemudian menentukan rule base untuk $\mathrm{Ki}$.

$$
\begin{array}{lll}
\text { If } \mathrm{X}=\mathrm{BK} & \text { Then } \mathrm{K}_{\mathrm{i}} & =1,892985981 \\
\text { If } \mathrm{X}=\mathrm{BS} & \text { Then } \mathrm{K}_{\mathrm{i}}=2,20533539 \\
\text { If } \mathrm{X}=\mathrm{BB} & \text { Then } \mathrm{K}_{\mathrm{i}}=7,721486311
\end{array}
$$

Pernyataan diatas merupakan rule base untuk pencarian nilai Ki. Apabila semakin besar pembebanan maka semakin besar nilai Ki yang digunakan.

Fungsi keanggotaan untuk input pada kontroler fuzzy PI digunakan untuk mengubah nilai $\mathrm{Kp}$ dan $\mathrm{Ki}$ pada setiap pembebanan, maka input fungsi keanggotaan berupa nilai tegangan pembebanan. Karena sistem pengaturan kecepatan motor BLDC memiliki pembebanan minimal, nominal, dan maksimal maka pada fungsi keanggotaan memiliki 3 anggota. Berikut ini fungsi keanggotaan dari input kontroler fuzzy. 


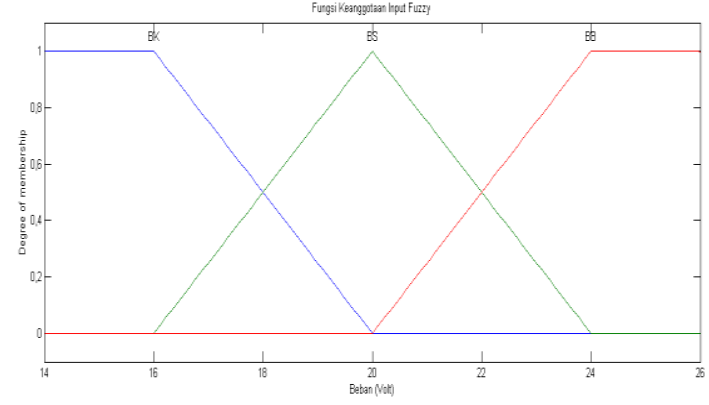

Gambar 11 Fungsi Keanggotaan Input

Pada Gambar 11 dapat dilihat bahwa jenis fungsi keanggotaan yang dipakai adalah jenis triangular. Fungsi keanggotaan input kontroler fuzzy terdiri dari 3 fuzzy set yaitu BK, BS, dan BB.

Pada fungsi keanggotaan output terdapat 3 anggota pada setiap $\mathrm{Kp}$ dan Ki. Bentuk dari fungsi keanggotaan hanya berupa konstanta atau singleton dari nilai $\mathrm{Kp}$ dan Ki. Proses defuzzifikasi menggunakan metode center average yaitu nilai $\mathrm{Kp}$ dan Ki yang telah didapatkan dikalikan dengan nilai bobot pada tiap rule-nya kemudian hasil kali antara weight dengan nilai Kp dan Ki dijumlahkan dan dibagi dengan jumlah total bobot.

\section{Perancangan Kontroler PI}

Parameter kontroler PI didapatkan dengan tuning neuro fuzzy. Blok diagram dan persamaan kontroler PI ditunjukkan pada Persamaan 16.

$$
m v(t)=\left(K_{P} e(t)+\frac{1}{T_{i}} \int_{0}^{t} e(t) d t\right)
$$

Komponen kontroler PI terdiri dari dua jenis yaitu proporsional dan integratif. Komponen proposional dan integral dapat dipakai bersamaan maupun sendiri-sendiri tergantung dari respon yang kita inginkan terhadap suatu plant.

\section{PENGUJIAN DAN ANALISIS}

\section{A. Simulasi Pengujian Kontroler PI berbasiskan Neural-} Fuzzy Hibrida Adaptif

Pembebanan dan hasil respon simulasi dengan kontroler PI berbasiskan Neural-Fuzzy Hibrida Adaptif dapat dilihat pada Gambar 12, 13 dan 14. Setpoint yang diberikan sebesar 1300 RPM dan beban yang digunakan adalah beban minimal pada 0-40 detik, beban nominal pada 41-70 detik, kemudian beban maksimal pada 71-99 detik. Karakteristik respon hasil simulasi memiliki settling time 11 detik, overshoot sebesar $1,5 \%$, dan time constant sebesar 5 detik.

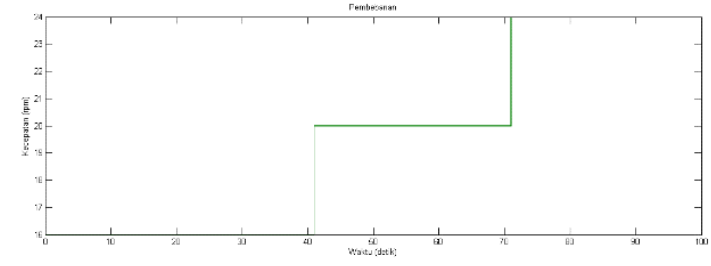

Gambar 12 Pembebanan pada Motor BLDC

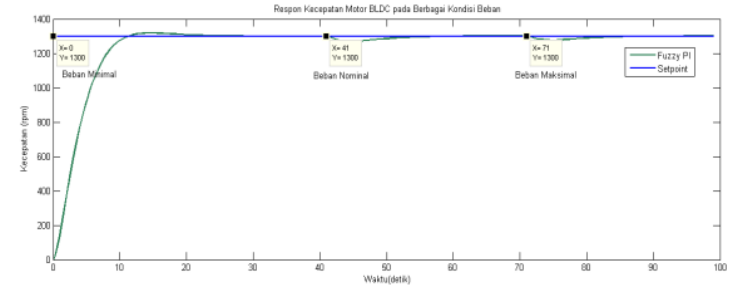

Gambar 13 Respon Kecepatan Motor BLDC pada berbagai Beban

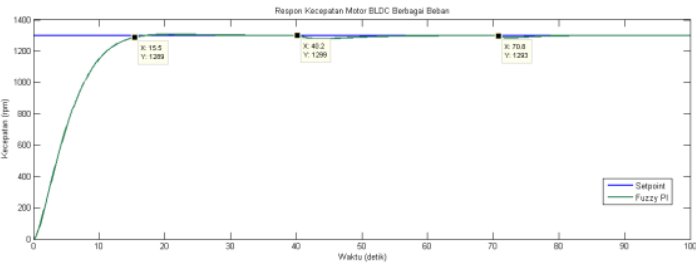

Gambar 14 Respon Kecepatan Motor BLDC pada berbagai Beban 2

B. Implementasi Kontroler PI berbasiskan Neural-Fuzzy Hibrida Adaptif

Pada implementasi sistem diberikan setpoint berupa sinyal step yang bernilai $1300 \mathrm{rpm}$. Pengujian dilakukan pada setiap beban dengan setpoint yang sama. Setelah itu respon motor BLDC dianalisis dengan mencari nilai settling time, overshoot, dan time constant. Respon kecepatan motor BLDC ketika beban minimal, nominal, maksimal, dan berbagai beban ditunjukkan pada Gambar 15, 16, 17, dan 18 .

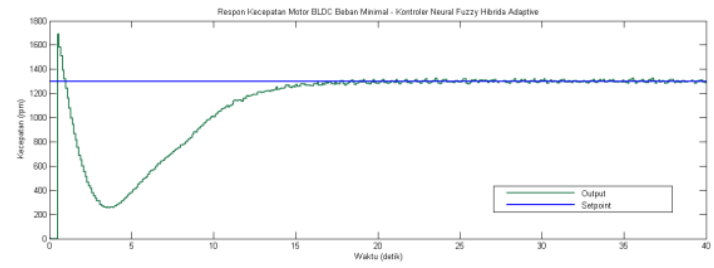

Gambar 15 Implementasi Respon Kecepatan Motor BLDC Beban Minimal

Setpoint kecepatan motor BLDC yang diberikan sebesar 1300 RPM dan beban yang digunakan adalah beban minimal dari 0-40 detik. Karakteristik respon hasil simulasi memiliki settling time 15 detik dan memiliki overshoot sebesar 1,5\%, dan time constant 8 detik.

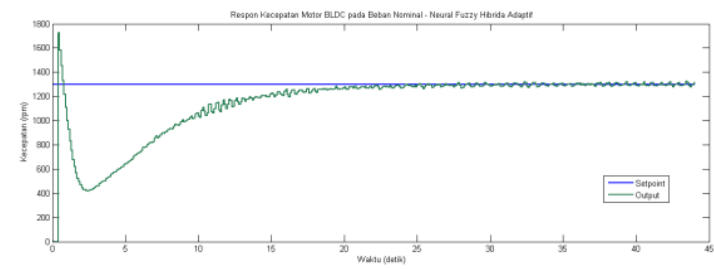

Gambar 16 Implementasi Respon Kecepatan Motor BLDC Beban Nominal

Setpoint kecepatan motor BLDC yang diberikan sebesar 1300 RPM dan beban yang digunakan adalah beban nominal dari 0-40 detik. Karakteristik respon hasil simulasi memiliki settling time 17,7 detik dan memiliki overshoot sebesar 1,3\%, dan time constant 9 detik.

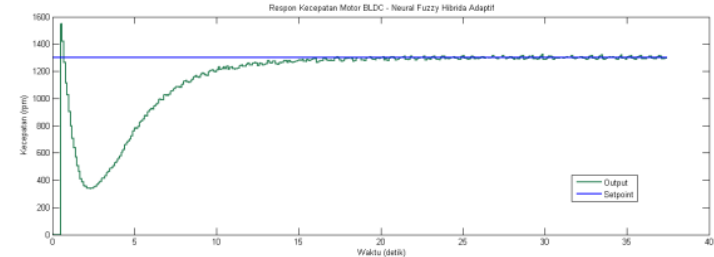

Gambar 17 Implementasi Respon Kecepatan Motor BLDC Beban Maksimal Setpoint kecepatan motor BLDC yang diberikan sebesar 1300 RPM dan beban yang digunakan adalah beban maksimal dari 0-40 detik. Karakteristik respon hasil simulasi memiliki settling time 13 detik dan memiliki overshoot sebesar $1,1 \%$, dan time constant 5 detik. 


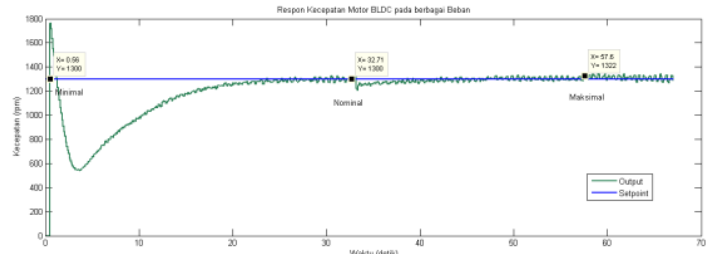

Gambar 18 Implementasi Respon Kecepatan Motor BLDC pada berbagai BebaSn

Setpoint kecepatan motor BLDC yang diberikan sebesar 1300 RPM pada berbagai beban. Karakteristik respon hasil simulasi memiliki settling time 20 detik dan memiliki overshoot sebesar $1,1 \%$, dan time constant 7,7 detik.

\section{KESIMPULAN}

Dari analisis yang telah dilakukan terhadap hasil simulasi maka dapat disimpulkan bahwa pengaturan kecepatan menggunakan kontroler PI berbasiskan Neural Fuzzy Hibrida Adaptif menghasilkan respon pada berbagai beban dengan karakteristik respon hasil simulasi memiliki settling time 11 detik, overshoot sebesar $1,5 \%$, dan time constant sebesar 5 detik sedangkan terhadap hasil implementasi memiliki karakteristik respon settling time 20 detik, overshoot sebesar $1,1 \%$, dan time constant 7,7 detik.

\section{DAFTAR PUSTAKA}

[1] M. Safrurriza, "Desain Sistem Pengaturan Kecepatan Motor Arus Searah Tanpa Sikat Menggunakan PID Mutiobjektif Berdasarkan Algoritma Genetika”, Tugas Akhir, Jurusan Teknik Elektro, Institut Teknologi Sepuluh Nopember, Surabaya, 2016.

[2] Guntur P., "Perancangan Kontrol Kecepatan Motor Arus Searah Tanpa Sikat Menggunakan Sliding Mode Berbasis PID”, Tugas Akhir, Jurusan Teknik Elektro, Institut Teknologi Sepuluh Nopember, Surabaya, 2016.

[3] Fairuzza D., "Pengaturan Kecepatan Motor Brushless DC Menggunakan Kontroler Fuzzy Berbasis Linear Quadratic Regulator", Tugas Akhir, Jurusan Teknik Elektro, Institut Teknologi Sepuluh Nopember, Surabaya, 2016.

[4] Mansouri, Mahdi, "Hybrid Adaptive Neuro Fuzzy Tuned PI", $4^{\text {th }}$ Power Electronics, Drive Systems \& Technologies Conference, Februari, 2013. 